\title{
Intention to Patronise Zakat Institution at Kwara State, Nigeria: An Application of the Decompose Theory of Planned Behaviour
}

\author{
Aishat Abubakar Sahban, ${ }^{1, \text { a }}$ Fuadah Johari ${ }^{2, \text { b, * }}$ \\ ${ }^{1,2}$ Faculty of Economics and Muamalat, \\ Universiti Sains Islam Malaysia (USIM), Nilai, Negeri Sembilan, Malaysia (71800) \\ a $\underline{\text { aishatabubakar3232@ gmail.com, }}{ }^{\text {b }}$ fuadah@usim.edu.my
}

*Corresponding Author

DOI: https://doi.org/10.22219/jes.v6i1.15234

Check for updates

\begin{tabular}{|c|c|}
\hline \multirow{3}{*}{$\begin{array}{l}\text { Keywords: } \\
\text { Zakat }\end{array}$} & ABSTRACT \\
\hline & Patronage is one of the major problems facing zakat institutions in Nigeria. \\
\hline & This study aims to analyze the increased zakat collection by examining \\
\hline Institution & which factor can encourage patronage of zakat institution in order to \\
\hline Patronage; & increase zakat collection for proper care of destitute in the state and help \\
\hline Zakat payers; & zakat managers to understand why they should encourage zakat payers \\
\hline Islamic Social & with their behavior to be honest and trusted to manage the Muslims \\
\hline Finance; & wealth. The quantitative research method was applied, a survey \\
\hline Kwara State. & $\begin{array}{l}\text { questionnaire was conducted among zakat payers, and potential zakat } \\
\text { pavers in Kwara state and a total of } 314 \text { completed survey questionnaires }\end{array}$ \\
\hline & were collected and subjected to structural equation modeling. This study \\
\hline & $\begin{array}{l}\text { results revealed that attitude and subjective norms influence the zakat } \\
\text { payers' intention to patronize the zakat institution in Kwara state, Nigeria. }\end{array}$ \\
\hline & This research concluded that attitude and subjective norms have positive \\
\hline & $\begin{array}{l}\text { effects on the intention of zakat payers to patronize zakat institutions in } \\
\text { Kwara State. }\end{array}$ \\
\hline
\end{tabular}

Article Info:

Submitted: 12/12/2020

Revised:

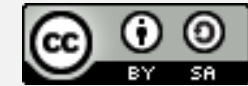

This work is licensed under a Creative Commons Attribution-ShareAlike 4.0 International (CC BY-SA 4.0)

29/12/2020

Submitted:

05/12/2020

Published:

$15 / 01 / 2021$

How to cite: Sahban, A. A., \& Johari, F. (2021). Intention to Patronise Zakat Institution at Kwara State, Nigeria: An Application of Decompose Theory of Planned Behaviour. Falah: Jurnal Ekonomi Syariah, 6(1), 1-16. https://doi.org/10.22219/jes.v6i1.15234 


\section{INTRODUCTION}

Zakat is regarded as one of its five pillars of Islam. Zakat is a certain proportion of wealth which individual has to give each year to the people entitled to it. Zakat means "purification" and "growth" (Rahman, et. al., 2019; Saad \& Al Foori, 2020; Takril \& Othman, 2020; Marlina, Maifizar, \& Risma, 2020). Act of giving zakat means purifying one's wealth to get Allah's blessing to make it increase in goodness. Paying zakat is not only to purify the property, but it will also purify the heart from greediness and materialism (Adachi, 2018; Alfaizin, et. al., 2018; Abdurraheem \& Suraju, 2018; Mansor, et. al., 2019; Hossain, et, al., 2020; May, 2020). Zakat is of two types which are zakat fitrah (al-fitr) and zakat from earnings (al-mal). Zakat al-fitr means a flat fee or levy imposed upon each person at the end of Ramadan fasting (Esack, 2013; Ali, 2014; Solehudin, 2017; Ibrahim, 2018). Zakat al-mal signifies a religious levy on wealth. It is an obligation to all Muslims whom their wealth reach nisab and they should give $2.5 \%$ of wealth and asset each year to categories of people who mention in Quran (Adebayo, 2020). The sum of zakat that an individual need to pay depends on the amount of money and the type of assets of the individual (Beik \& Arsyianti, 2016; Belabes, 2019). As stated by (Ahmad, 2019), zakat is the wealth that closes the gap between the rich and the poor.

Zakat is meant to assist the poor and the destitute in Muslim society to partake in economic activities and have a decent standard of living (Ahmad Baliqis, 2016). Zakat is a tool to achieve socio-economic justice to eradicate poverty. This goal can be realised if it is properly collected and disbursed as demanded by the Shariah by being collected and disbursed by the state to the beneficiaries (Halimatusa'diyah, 2015; Jahar, 2015; Al-Banna \& Michael, 2019; Kuran, 2020; Retsikas, 2020). If there is no Islamic government, it is anticipated to be managed by an organised body that is selected by Muslims. Non-governmental organisations mostly establish zakat institutions in Nigeria and private individuals apart from some Northern states which run under a department of government coordinating its activities (Isa, 2010). Because Nigeria is a secular country with people of different religious, therefore, the administration of zakat falls under Islamic institutions, non-governmental organisations, and individuals (Muhammad \& Saad, 2016; Farouk, Idris \& Saad, 2018; Ahmad, 2019; Saad \& Farouk, 2019). Zakat has been practised in Northcentral and South-west Nigeria individually without any government support. Recently, the motivation by some Islamic organisations in reviving the third pillars of Islam has been welcomed with much hope and appreciation (Muhammad \& Saad, 2016; Farouk, Idris \& Saad, 2017; Farouk, Idris \& Saad, 2018). Aside from some individuals paying their zakat when due, these organisations identify zakat payers through personal contact by their field workers. 
Vol. 6 No. 1 (2021)

ISSN (print): 2502-3918 | ISSN (online): 2502-7824

The major problem facing zakat institutions in Nigeria (Muhammad \& Saad, 2016; Ibrahim, 2017; Farouk, Idris \& Saad, 2018) generally, and Kwara State specially is low zakat income from zakat payers to zakat institution, which prompts the intention of this researcher to examine the factors capable of influencing zakat payers to patronise zakat institutions in Kwara State (Abdussalam, Johari \& Alias, 2015). According to Abdussalam (2015), Kwara State is considered one of the oldest states in Nigeria which were created from the four-national region on 27 May 1967. The state is known as the state of harmony because of the easy-going coexistence among its multiracial and varied population of 2.4 million (Härmä, 2016; Amusan, Saka, \& Ahmed, 2017; Maigida, 2018; Jawondo, 2019; Mahmood, 2019). It has an overwhelming majority of Muslims, about $77 \%$ of the state population are Muslims. The state is divided into 16 (16) local government for administrative convenience (Abdussalam, 2015) with a total landmass of 32,500 square kilometres. The state comprises several ethnicities made up of Fulani, Hausa, Yoruba, Nupe, and Bariba. Kwara State is in the North Central (including Kogi, Nassarawa, Benue, Niger, Plateau and FCT Abuja) region and is a geopolitical zone with an agricultural economy.

Even though the Qur'an emphasised on zakat payment and punishment of those who refuse payment, the collection of zakat in places like Kwara State is still low. In regard of factors that affect the zakat institutions, a research conducted in Kano, Nigeria, by Muhammad \& Saad (2016) among 105 respondents found that attitude toward zakat evasion affects the intention to pay zakat. Similarly, Saad \& Haniffa (2014) stated that an in-depth study of the accountability practices of zakat institutions might help to recognise the basic factors that result in inefficient zakat disbursement. According to Abioye et. al., (2011); Muhammad \& Saad, (2016); Ghani, et. al., (2018), zakat payers' trust is important than zakat institutions because its deficiency will undercut the institutional efficiency of zakat. A satisfactory level of trust should be retained between Muslims and zakat institutions or else the potential zakat payers would desire to pay their zakat directly to the poor or needy, instead of through the zakat institutions (Ahmed, Johari, \& Wahab, 2017; Ahmad, 2019).

Studies on zakat administration have identified several challenges concerning the management of zakat funds. The high percentage of zakat payers and recipients are not satisfied with the management process resulting in low patronage by zakat payers (Muhammad \& Saad, 2016). In accordance with the fundamental principles of zakat, the zakat institution has to be established within Muslim society (Hasbi et. al., 2017). If zakat institutions are well patronising, then it can positively affect the socio-economic status of the zakat recipients (Farikha \& Ghoniyah, 2018; Mohsin, 2013). Moreover, if the Muslim Ummah pays their zakat poverty could decrease to zero levels (Hasbi., et. al., 2016). 
Prior studies explored on several factors that affect the willingness of zakat payers to pay zakat at zakat institution (Taha et. al., 2017; Salwa et al., 2018; Tsalas, et al., 2019). On the other hand, many studies on zakat have demonstrated the predictive ability of TP, caused by a multidimensional of its elements (Saad, et. al., 2015; Hafizah et. al., 2016; Hashim \& Leha, 2017). However, few studies have been undertaken by examining and combining many factors that can influence the patronage of zakat institutions. This paper aims to increase zakat collection by examining which factor can encourage patronage of zakat institution in order to increase zakat collection for proper care of destitute in the state and help zakat managers to understand why they should encourage zakat payers with their behaviour to be honest and trusted to manage the Muslims wealth. Because patronage is one of the major problems facing zakat institutions in Nigeria.

\section{RESEARCH METHOD}

In other to enhance the validity of the study result, the researcher should consider choices methods and procedures for data collection and analysis appropriately. In reply to this, a survey was conducted in Kwara state, Nigeria. The sample was chosen using a purposive method. A total of 350 zakat payers and potential zakat payers from sixteen local government in Kwara state Nigeria, were chosen to facilitate an effective response. In-House physical data collection questionnaires applied with selfadministered, questionnaires distributed to the respondents in which 314 were completed and useful. Also, according to Krejcie \& Morgan (1970), the minimum number of allowed sample based on a population more than 1 million was 384 respondents, and not all Kwarans are Muslims while not all, Muslims are zakat payers, this explains why the researcher involved 350 respondents for this study. However, 314 completed survey questionnaires were used for further analysis. The data were analyses using structural equation modelling (SEM, AMOS).

In this study, the decomposed theory of planned behaviour (DTPB) explores attitudes, subjective norms, and perceived behavioural control by decomposing them into belief-based indirect measures (Ajzen \& Fishbeing, 1980; Ajzen, 1991; Taylor \& Todd, 1995). For instance, knowledge, and religious obligation, explain attitudes: family influence and media awareness explain subjective norms; trust, transparency and zakat manager justify perceived behavioural control.

This study chooses this theoretical model to discover the perceptions of intentions of people to patronise zakat institution. Figure 1 show a details of conceptual framework of this study; 
V

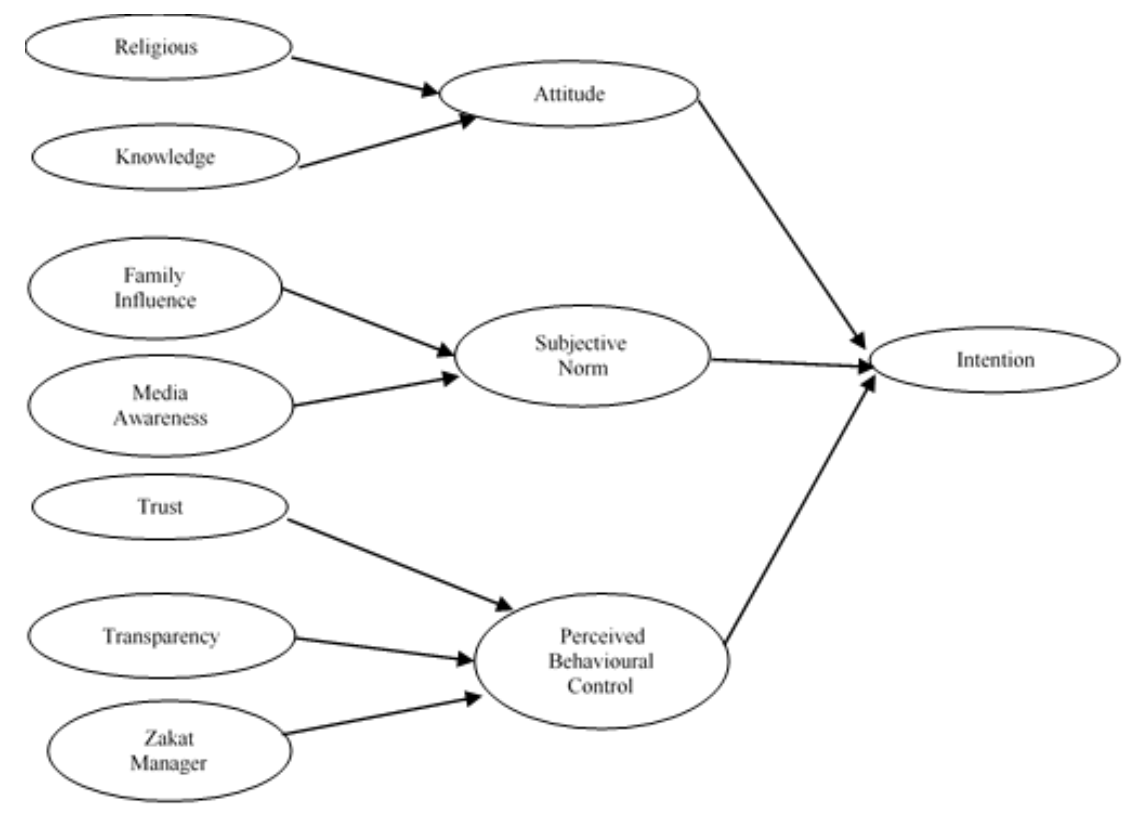

Figure 1. Conceptual framework for zakat payers' intention to patronise zakat institutions based on the decomposed theory of planned behaviour
Falah: Jurnal Ekonomi Syariah

Vol. 6 No. 1 (2021) pp. 01-16

ISSN (print): 2502-3918 | ISSN (online): 2502-7824

Journal Homepage: http://ejournal.umm.ac.id/index.php/JES

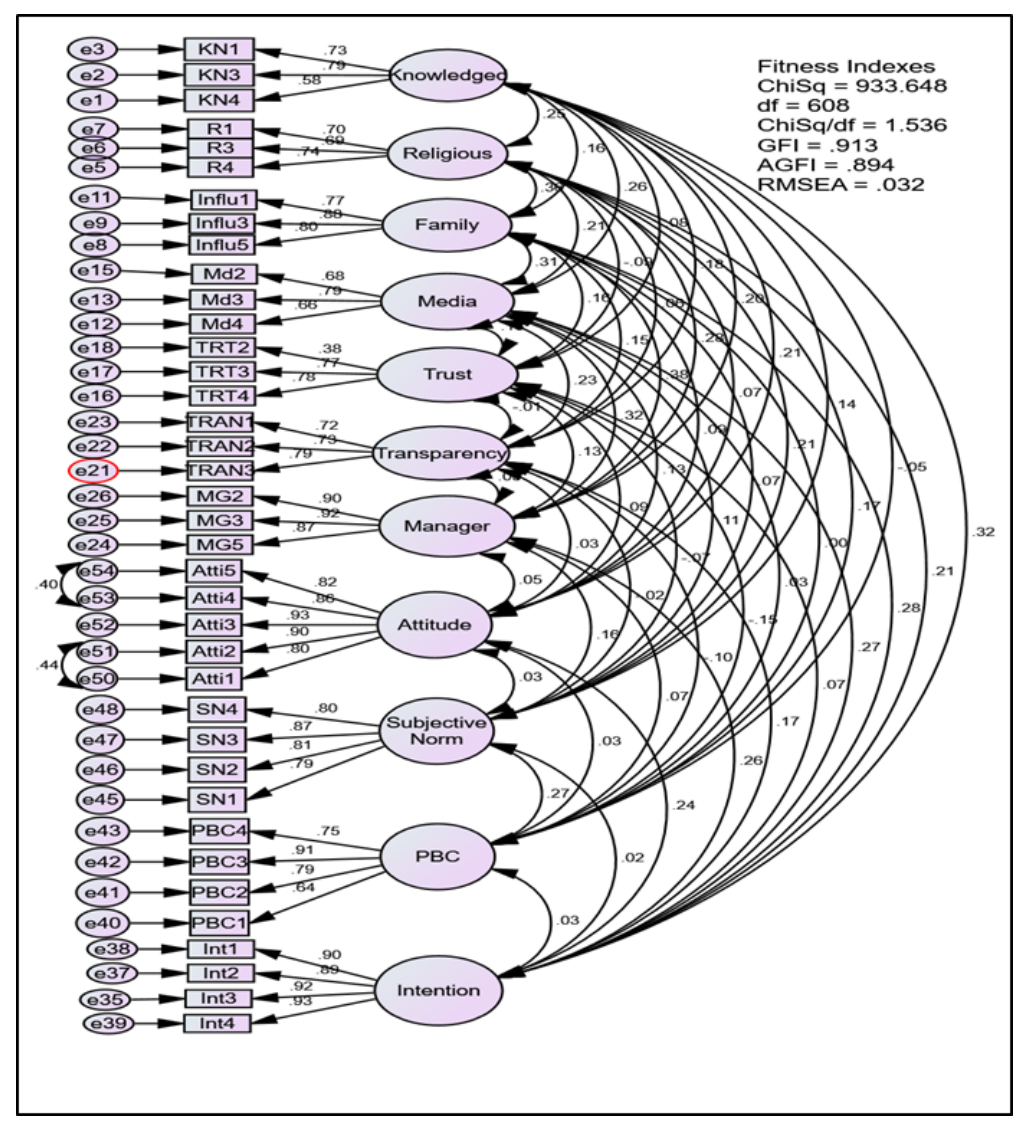

Figure 2. The Pooled Confirmatory Factor Analysis (CFA) of The Factors 


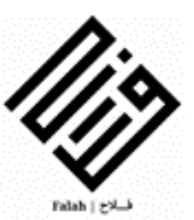

Falah: Jurnal Ekonomi Syariah

Vol. 6 No. 1 (2021) pp. 01-16

ISSN (print): 2502-3918 | ISSN (online): 2502-7824 Journal Homepage: http://ejournal.umm.ac.id/index.php/JES

As illustrated in Figure 2, the seven different measurement models were evaluated for construct validity and uni-dimensionality. The main measurement item distillation was conducted with numerous iterations of CFA through maximum likelihood estimation (MLE). The reason behind this purification of items was to search for model specifications (Hair et. al., 2010). Several indicators, for example, in the modification indexes, squared multiple correlations and standard residuals, the correlation was examined to verify whether the modification remained needed. In accordance with the recommendations made by Hair et. al. (2010); Min \& Mentzer (2004), before final deletion of any measuring item, qualitative review or theoretical assessment was made. In this purification process, a total of 10 items were cast off from further analysis. We have used the pooled CFA for all the constructs in the model.

The hypotheses were between the independent variables (knowledge and religious,) and the dependent variable (attitude) and also, between independent variables (attitude, subjective norm and perceived behavioural control) and dependent variable (intention). Moreover, the hypotheses have also taken into account the test of intention as an interpretation of patronage. The structural model was then evaluated for the validity of the relationship. The hypotesis of this research can be formulated as follows:

$\mathrm{H}^{1}$ : Attitude of zakat payers has positive effects on their behavioural intention to patronise zakat institutions.

$\mathrm{H}^{1 \mathrm{a}}$ : zakat payers' religious has positive effects on their attitude to pay their zakat to zakat intuitions.

$\mathrm{H}^{1 \mathrm{~b}}$ : zakat payers' knowledge has positive effects on their attitude to pay their zakat to zakat intuitions.

$\mathrm{H}^{2}$ : Subjective norms of zakat payers have positive effects on their behavioural intentions to patronise zakat institutions.

$\mathrm{H}^{2 \mathrm{a}}$ : Family influence has positive effects on zakat payers' subjective norms to pay their zakat to zakat institutions.

$\mathrm{H}^{2 b}$ : Media awareness has positive effects on zakat payers' subjective norms to pay their zakat to zakat institutions.

$\mathrm{H}^{3}$ : The perceived behavioural control of zakat payers has positive effects on their behavioural intention to patronise zakat institutions.

$\mathrm{H}^{3 \mathrm{a}}$ : Trust has positive effects on zakat payers' perceived behavioural control to pay their zakat to zakat institutions.

$\mathrm{H}^{3 \mathrm{~b}}$ : transparence has positive effects on the zakat payers' perceived behavioural control to pay their zakat to zakat institutions. 
Vol. 6 No. 1 (2021)

ISSN (print): 2502-3918 | ISSN (online): 2502-7824

$\mathrm{H}^{3 \mathrm{c}}$ : zakat manager has positive effects on the zakat payers' perceived behavioural control to pay their zakat to zakat institutions.

\section{RESULT AND DISCUSSION}

The results in the figure 3 demonstrates the bond between the constructs in the study. In this situation, the structural model was specified by the results obtained from the measurement models. From here, the bond between the independent and dependents variables was built based on the proposed conceptual model. This structural model was formed to test the hypotheses of the study.

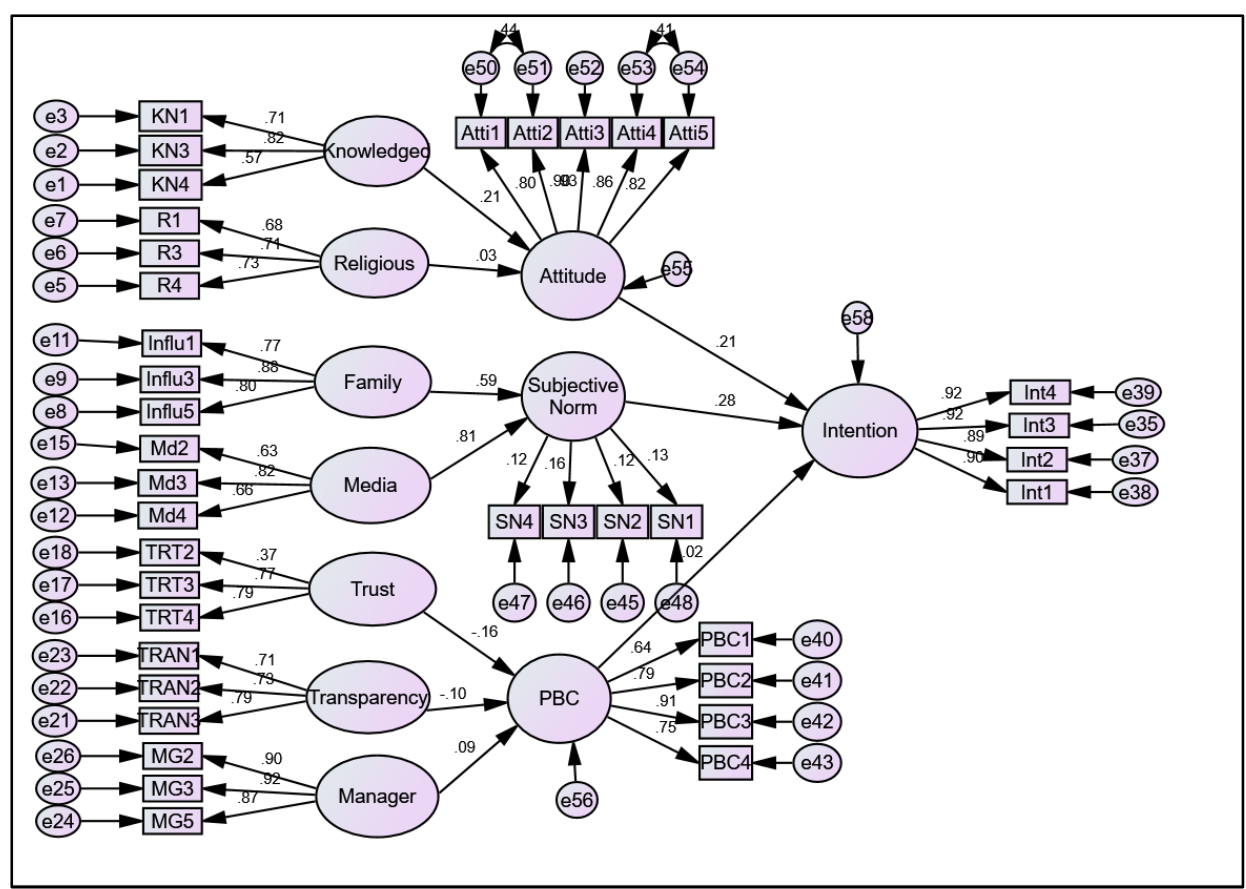

Figure 3. Standardised Regression Weight for zakat payers' intention to patronise zakat institutions based on the decomposed theory of planned behaviour

As revealed on the summary model in Figure 3, found that the score for $\mathrm{X} 2 / \mathrm{df}$ is 1.536 signifies a satisfactory fitness index between both the hypothesised model and the relevant data. In other words, this result is steady with the proposed acceptable ranges of 3 to 1 by Hair et al. (2010). As discoursed earlier, the general fit of the model can be assessed through several indicators. So, in order to evaluate the fitness of the structural model, this study selected several most often reported test statistics. The model fit indices results signpost that the model have an acceptable model fit $(X 2=933.648$; $\mathrm{df}=$ 608; X2/df = 1.536; P=0.000; GFI = 913; AGFI = 894; RMSEA =0.032). The result from a structural model is fit and could be used for hypotheses testing. 
Other indices were used in this measuring model fit. They all show a good fit which shows that the model can be considered a good fit. The details of the fitness index are presented in Table 1,

Tabel 1. Results of Fitness Index on the Measurement Model

\begin{tabular}{lccc}
\hline \multicolumn{1}{c}{ Name of category } & Name of index & Index Value & \multicolumn{1}{c}{ Comments } \\
\hline Absolute fit & RMSEA & 0.036 & The required level is achieved \\
\cline { 2 - 4 } & GFI & 0.919 & The required level is achieved \\
\hline Incremental fit & AGFI & 0.900 & The required level is achieved \\
\hline Parsimonious fit & Chisq/df & 1.410 & The required level is achieved \\
\hline
\end{tabular}

On the other hand, according to the results of the structural model analysis described in table 2, hypotheses are tested for the respective paths in the model. Among all the constructs in the model, it can be noted that attitude emerged as the main predictor of intention to patronise zakat institutions with $(\beta=0.213, p$-value $=0.000)$, followed by subjective norm $(\beta=0.282$, $p$-value $=0.023)$, and the least predictor in the model is perceived behavioural control with $(\beta=0.682$, $p$-value $=0.019)$.

Tabel 2. Results of of the Structural Model Analysis

\begin{tabular}{|c|c|c|c|c|c|c|c|}
\hline \multicolumn{8}{|c|}{ CFA Results for the Measurement Model after Item Deletion } \\
\hline & & & Estimation & S.E. & C.R. & $\mathbf{P}$ & Label \\
\hline Trust & $<---$ & PBC & .654 & .289 & 2.818 & .005 & \\
\hline Transparency & $<---$ & PBC & .764 & & & -085 & Not-significant \\
\hline Manager & $\begin{array}{ll}<-- \\
\end{array}$ & PBC & .603 & .196 & 2.564 & .010 & Significant \\
\hline Media & $<---$ & Subjective Norm & .643 & .831 & 2.211 & .027 & Significant \\
\hline Family & $<--$ & Subjective Norm & .909 & .650 & 1.810 & .070 & Not-significant \\
\hline Knowledge & $<--$ & Attitude & .813 & 2.519 & 2.028 & .043 & Significant \\
\hline Religious & $<--$ & Attitude & .798 & 1.926 & 2.058 & .040 & Significant \\
\hline Intention & <--- & Attitude & .331 & .707 & 2.151 & .031 & Significant \\
\hline Intention & $<---$ & Subjective Norm & .730 & 1.081 & 2.536 & .011 & Significant \\
\hline Intention & $<--$ & $\mathrm{PBC}$ & .140 & .107 & 1.576 & .115 & Not-significant \\
\hline
\end{tabular}

According to the findings from the SEM analysis, attitude appeared as the core predictor of intention to patronise zakat institutions. This discovery is consistent with the previous study on predicting compliance intention on zakat employment income in Malaysia by Saad \& Haniffa, (2014) which found that zakat payers' intention is more influenced by attitude than other factors. Furthermore, these results illustration that attitude is statistically significant at the level of 0.000 concerning the intention to 
Vol. 6 No. 1 (2021)

ISSN (print): 2502-3918 | ISSN (online): 2502-7824

patronise zakat institutions. Thus, it shows that the greater the attitude, the higher the intention to patronise the zakat institution in Kwara state, Nigeria.

Based on the result of the study, it can be proposed that the attitude significantly affects the intention to patronise zakat institutions positively. The findings support the hypothesis: attitude positively affects the intention to patronise zakat institutions. Therefore, hypothesis 1 is supported. The findings also illustrated that perceived behavioural control is the minimum predictor in the model. However, have been the least predictor does not mean it is not significant; it estimates 0.019 betas of the path, and significant at 0.682 . The finding shows that perceived behavioural control has negative effects on the intention to patronise zakat institutions. This finding is supported with the former study on negative perception towards zakat institution in managing the distribution of zakat funds by Sanep \& Hairunnizam (2004) which revealed that zakat compliance behaviour could be predicted by his or her perception toward zakat institutions. Therefore, the more the zakat payers control their decisions, the less their intention to patronise zakat institutions in Kwara state. Hence, it can be proposed that perceived behavioural control negatively affects the intention to patronise zakat institutions. Thus, the discoveries support the hypothesis: Perceived behavioural control positively affects the intention to patronise zakat institutions. Hence, hypothesis 3 is no longer supported.

The second prominent factor that affects the intention to patronise the zakat institution is the subjective norm. It was additionally a significant predictor for the patronage of zakat institutions. Thus, it shows that there is a positive effect of subjective norm on the intention to patronise zakat institutions. As the zakat payers and potential zakat payers' subjective norm becomes positive regarding the patronage of zakat institutions, the willingness to patronise zakat institution will increase. This finding is supported by Azman and Bidin (2015) reported that the subjective norm toward paying zakat significantly influences zakat compliance behaviour on saving.

Consequently, it can be suggested that subjective norm has a positive and significant effect on the intention to patronise zakat institutions in Kwara state as generalised in Ajzen (2006) TPB. Hence, this result supports the hypothesis: The zakat payers' subjective norm positively affects the intention to patronise zakat institutions. Therefore, hypothesis 2 is supported.

This study also decomposed attitude into the appropriate variables. As proposed by Ajzen (1991), the TPB can include other external variables if it captures a substantial proportion of the variance in the intent or behaviour. So, this study decomposed the construct into relevant variables. Attitude contained two variables which are knowledge and religious. The result from SEM analysis indicates a definite path coefficient on one constructs concerning attitude. Therefore, hypothesis $1 \mathrm{~b}$ : knowledge of zakat payers has 
a positive effect on their attitude to patronise zakat institutions; 1a: religious of zakat payers have negative effects on their attitude to patronise zakat institutions. This is contradicting with the previous study by Haji-Othman et. al. (2017) found that Islamic religious sentiment has a positive and significant relationship with intention. Furthermore, Hashim \& Leha (2017) found that the correlation between attitudes, religious of zakat, the satisfaction of zakat authority, and obligation to pay zakat on employment income is significant and has a positive relationship. Therefore, hypotheses $1 \mathrm{a}$ is not supported, and $1 \mathrm{~b}$ is supported.

Moreover, the study also decomposed the variables into different relevant zakat variables. Hence, the subjective norm was divided into family influence and media awareness. The results from SEM indicate that the subjective norm is significantly affecting behavioural intention to patronise with ( $\mathrm{p}$-value $=0.23$ ), and media awareness is significantly affected it with (p-value $=0.023$ ). Therefore, hypothesis $2 \mathrm{a}$ : Family influence of zakat payers has positive effects on their Subjective norms to patronise zakat institutions is also supported. While the hypothesis $2 \mathrm{~b}$ : media awareness of zakat payers has a positive effect on their subjective norm to patronise zakat institutions.

Furthermore, perceived behavioural control was decomposed into three factors in this study, which are trust, transparency, and zakat managers. The results from SEM indicate that perceived behavioural control affects trust and transparency only, while zakat managers are not-significant. The findings support hypothesis $3 \mathrm{a}$, and $3 \mathrm{~b}$. Hypothesis 3a: trust of zakat payers has positive effects on their perceived behavioural control to patronise zakat institutions. However, hypothesis $3 \mathrm{~b}$ : transparency has positive effects on their Perceived behavioural control to patronise zakat institutions is supported. Thus, following the rule of this model, the more positive the attitude and subjective norms are towards patronage of zakat institution, the greater the perceived behavioural control, and the stronger the individual's intention to patronise zakat institutions. This study support the result of the study by Saad \& Haniffa, (2014); Abioye et. al., (2011); Muhammad \& Saad, (2016); Ghani, et. al., (2018), Ahmed, Johari, \& Wahab, 2017; Ahmad, 2019).

\section{CONCLUSION}

The result indicated that trust and transparency have been the most important factor in measuring perceived behavioural control. It is indicates that zakat institution and zakat managers need to be trusted by zakat payers to make them patronise it. Therefore, this study suggests that zakat institution should consider trust, transparency and zakat managers in order to win the heart of a philanthropist. Therefore, it can be recommended that the higher the intention of zakat payers, the higher the patronage of zakat institutions. Finally, this study shows that a positive attitude, support from 
Vol. 6 No. 1 (2021)

ISSN (print): 2502-3918 | ISSN (online): 2502-7824

subjective norms and perceived behaviour control are important factors for positive behaviour intention towards the patronage of zakat institutions.

However, the current study only examined the Kwara State in Nigeria, future research may add wider population and sample of the study involve all-state in Nigeria concerning about zakat institution patronage, because it is vital issue which is supposed to address nationwide

\section{REFERENCES}

Abdurraheem, H., \& Suraju, S. B. (2018). Taming poverty in Nigeria: language, zakat and national development. QIJIS (Qudus International Journal of Islamic Studies), 6(1), 1-24. https://doi.org/10.21043/qijis.v1i1.3278

Abdussalam, A. A. (2012). Muslims of Kwara state: a survey. Nigeria Research Network (NRN) Background Paper, Department of International Development, Queen Eliszabeth House, University of Oxford (3), 1-11. Retrieved from https://www.qeh.ox.ac.uk/sites/www.odid.ox.ac.uk/files/BP3Abdussalam.pdf

Abdussalam, O. I. (2015). Impact of Youth Empowerment Scheme on Poverty Alleviation in Nigeria. International Journal of Business, Economics and Law, 8(3), 35-39. Retrieved from http://www.ijbel.com/wpcontent/uploads/2016/01/Econ-16.pdf

Abdussalam, O. I., Johari, F., \& Alias, M. (2015). Is zakah effective to alleviate poverty in a Muslim society?: A case of Kwara State, Nigeria. Global Journal Al Thaqafah, 5(1), 33-41. https://doi.org/10.7187/GJAT762015.05.01

Abioyea, M. M. O., Mohamad, M. H. S., \& Adnan, M. A. (2011). Antecedents of Zakat payers' trust: The case of Nigeria. International Journal of Economics, Management and Accounting, 19(3), 133-164. Retrieved from https://journals.iium.edu.my/enmjournal/index.php/enmj/article/view/204

Adachi, M. (2018). Discourses of Institutionalization of Zakat Management System in Contemporary Indonesia: Effect of the Revitalization of Islamic Economics. International Journal of Zakat, 3(1), 25-35. https://doi.org/10.37706/ijaz.v3i1.71

Adebayo, R. I. (2020, October). Utilizing Zakat for Attaining Sustainable Development Goals (SDGs) in Nigeria. In International Conference of Zakat (pp. 231-242). https://doi.org/10.37706/iconz.2020.233

Ahmad, M. (2019). An empirical study of the challenges facing zakat and waqf institutions in Northern Nigeria. ISRA International Journal of Islamic Finance. 11(2), 338-356. https://doi.org/101108/IJIF-04- 2018-0044

Ahmad, M. (2019). An empirical study of the challenges facing zakat and waqf institutions in Northern Nigeria. ISRA International Journal of Islamic Finance. 11(2), 338-356. https://doi.org/10.1108/IJIF-04-2018-0044

Ahmed, B. O., F. Johari, \& K. A. Wahab. (2014). Zakat and poverty alleviation: AlHayat Relief Foundation contributions in Ogun State, Nigeria: an overview. (Master Thesis, Universiti Sains Islam Malaysia). Retrieved from https://www.semanticscholar.org/paper/Zakat-and-poverty-alleviation\%3A-AlHayat-Relief-in-Ololade-Johari/a243c1e9d9c06430a2006be09b6da23afff42c2b

Ahmed, B. O., Johari, F., \& Wahab, K. A. (2017). Identifying the poor and the needy among the beneficiaries of zakat. International Journal of Social Economics. 44(4), pp. 446-458. https://doi.org/10.1108/IJSE-09-2015-0234 
Ajzen, I. (1991). The theory of planned behavior. Organizational behavior and human decision processes, 50(2), 179-211. Retrieved from https://www.dphu.org/uploads/attachements/books/books_4931_0.pdf

Ajzen, I. (2006). Constructing a TpB questionnaire: Conceptual and methodological considerations. Retrieved from http://www.unix.oit.umass.edu/tpb.measurement.pdf.

Azjen, I. (1980). Understanding attitudes and predicting social behavior. Englewood Cliffs NJ: Prentices Hall, Inc.

Alfaizin, A. W., Insani, T. D., \& Herianingrum, S. (2018). Zakat: Concept And Implications To Social And Economic (Economic Tafsīr Of Al-Tawbah: 103). Journal of Islamic Monetary Economics and Finance, 4(1), 117-132. https://doi.org/10.21098/jimf.v4i1.780

Al-Banna, M. A. K., \& Michael, I. (2019). Zakat and Its Socio-Economic Merits: A Holistic View towards Eradication of Poverty. In Socio-Economic Development: Concepts, Methodologies, Tools, and Applications (pp. 500-514). IGI Global.

Ali, J. A. (2014). Zakat and poverty in Islam. Clarke, Matthew und David Tittensor (Hg.). in Islam and Development. Exploring the Invisible Aid Economy. USA: Ashgate Publishing Limited. pp. 15-32.

Amilahaq, F., \& Ghoniyah, N. (2019). Compliance behavior model of paying zakat on income through zakat management organizations. Share: Jurnal Ekonomi dan Keuangan Islam, 8(1), 114-141. http://dx.doi.org/10.22373/share.v8i1.3655

Amusan, L., Saka, L., \& Ahmed, Y. B. (2017). Patriarchy, religion and women's political participation in Kwara state, Nigeria. Gender and Behaviour, 15(1), 8442-8461. Retrieved from https://journals.co.za/content/journal/10520/EJC$\underline{88 \mathrm{ec} 24 \mathrm{~b} 5 \mathrm{f}}$

Azman, F. M., \& Bidin, Z. (2015). Determinants of attitude toward zakat on saving. Australia Journal of Basic \& Applied Science, 9(31), 7-13. Reterieved from https://www.researchgate.net/profile/Zainol_Bidin/publication/282566400_Deter minants_of_attitude_toward_zakat_on_saving/links/5611f75708ae0fc513f305b4/ Determinants-of-attitude-toward-zakat-on-saving

Beik, I. S., \& Arsyianti, L. D. (2016). Measuring zakat impact on poverty and welfare using CIBEST Model. Journal of Islamic Monetary Economics and Finance, 1(2), 141-160. Retrieved from http://www.jimf-bi.org/index.php/JIMF/article/view/524

Belabes, A. (2019). Zakat as a Pluridimensional Concept. International Journal of Zakat, 4(1), 67-75. https://doi.org/10.37706/ijaz.v4i1.165

Ending Solehudin, E. S. (2017). The Zakat Reform of Management and the Zakat in Indonesia. International Journal of Political Science, Law and International Relations (IJPSLIR), 7(6), 9-30. Reterieved from http://digilib.uinsgd.ac.id/6631/

Esack, F. (2013). On being a Muslim: Finding a religious path in the world today. Simon and Schuster.

Farouk, A. U., Idris, K. M., \& Saad, R. A. J. (2018). Determinants of attitude towards zakat on employment income in Nigeria. International Journal of Banking and Finance, 13(1), 29-48. Retrieved from http://www.ejournal.uum.edu.my/index.php/ijbf/article/view/8497 
Vol. 6 No. 1 (2021)

ISSN (print): 2502-3918 | ISSN (online): 2502-7824

Farouk, A. U., Idris, K. M., \& Saad, R. A. J. B. (2018). Moderating role of religiosity on zakat compliance behavior in Nigeria. International Journal of Islamic and Middle Eastern Finance and Management. 11(3), 357-373. https://doi.org/10.1108/IMEFM-05-2017-0122

Farouk, A. U., Idris, K., \& Saad, R. A. J. (2017). The challenges of zakat management: a case of Kano state, Nigeria. Asian Journal of Multidisciplinary Studies, 5(7), 142-147.

Retrieved

from https://www.researchgate.net/profile/Ram_Al_Jaffri_Saad/publication/320867065 _The_Challenges_of_Zakat_Management_A_Case_of_Kano_State_Nigeria/links/ 59ffca88458515d0706e3aac/The-Challenges-of-Zakat-Management-A-Case-ofKano-State-Nigeria.pdf

Fauziah, F. (2020). Supply Chain Management of Zakat to Reduce Poverty and Improve Community Welfare (Case Study Baznas in Serang District). Int. J Sup. Chain. Mgt Vol, 9(2), 664-668. Retrieved from https://core.ac.uk/download/pdf/322571531.pdf

Ganiyev, A., \& Umaraliev, S. The role of zakat in the early stages of the islamic civilisation. EPRA International Journal of Multidisciplinary Research (IJMR), 6(6), 441-444. https://doi.org/10.36713/epra2013

Ghani, E. K., Aziz, A. A., Tajularifin, S. M., \& Samargandi, N. (2018). Effect of board management and governmental model on zakat payers' trust on zakat institutions. Global Journal Al-Thaqafah, 1, 73-86. Retrieved from http://www.gjat.my/gjat2018si/SI2018-05.pdf

Hair, J. F., Black W. C., Babin J. B. \& Anderson. R. E. (2010). Multivariate Data Analysis: A Global Perspective. ( $7^{\text {th }}$ ed) Upper Saddle River, NJ: Pretence.

Halimatusa'diyah, I. (2015). Zakat and social protection: the relationship between socioreligious CSOs and the government in Indonesia. Journal of Civil Society, 11(1), 79-99. https://doi.org/10.1080/17448689.2015.1019181

Härmä, J. (2016). School choice in rural Nigeria? The limits of low-fee private schooling in Kwara State. Comparative Education, 52(2), 246-266. https://doi.org/10.1080/03050068.2016.1142737

Hossain, M. S., Hasan, K. M., \& Khan, S. M. (2020). Factors Influencing Proper Zakah Payment in Dighalia Upazila of Khulna District, Bangladesh. European Journal of Business and Management Research, 5(2), 1-6. https://doi.org/10.24018/ejbmr.2020.5.2.292

Hu, L. T., \& Bentler, P. M. (1998). Fit indices in covariance structure modeling: Sensitivity to underparameterized model misspecification. Psychological Methods, 3(4), 424-453. https://doi.org/10.1037/1082-989X.3.4.424

Ibrahim, H. M. (2018). The Islamic Decision regarding giving Zakat-Al Fitr by money in Islamic fiqeh. Zanco Journal of Humanity Sciences, 22(5), 69-87. https://doi.org/10.21271/zjhs.22.5.5

Ibrahim, S. M. (2017). Towards Institutionalizing Zakat Management In Kano State, Nigeria: An Exposition (Doctoral dissertation, Universiti Sains Islam Malaysia). Retrieved

from https://d1wqtxts1xzle7.cloudfront.net/59810138/Final_Thesis_Copy2019062080513-45zuyt.pdf?1561054315=\&response-content-

Isa, M. (2010). The Role of Government Agencies in the Administration of Zakat in Some Selected States of Northern Nigeria, ((Doctoral dissertation, Usman 
Danfodiyo University Sokoto). Retrieved from

https://core.ac.uk/download/pdf/234674162.pdf

Jahar, A. S. (2015). Marketing Islam through zakat institutions in Indonesia. Studia Islamika, 22(3), 405-442. https://doi.org/10.15408/sdi.v22i3.2353

Jawondo, I. A. G. (2019). The Role of Muslim Scholars in Kwara Politics up to the Fourth Republic. IIUM Journal of Religion and Civilisational Studies, 2(1), 3952.

Retrieved

from https://journals.iium.edu.my/irkh/index.php/ijrcs/article/view/58

Krejcie, R. V., \& Morgan, D. W. (1970). Determining sample size for research activities. Educational and psychological measurement, 30(3), 607-610. https://doi.org/10.1177/001316447003000308

Kuran, T. (2020). Zakat: Islam's missed opportunity to limit predatory taxation. Public Choice, 182(3), 395-416. https://doi.org/10.1007/s11127-019-00663-x

Mahmood, A. M. (2019). Heterogeneous beliefs and practices amongst Muslims in Nigeria: a case study of Yoruba speaking people of Ilorin Kwara State (Master's thesis, Kuala Lumpur: International Islamic University Malaysia, 2019). Retrieved from http://studentrepo.iium.edu.my/handle/123456789/6509

Maigida, A. Y. (2018). Contemporary Islamic Education in Nigeria from the Rear View Mirror. American Journal of Educational Research, 6(4), 329-343. Retrieved from http://article.scieducationalresearch.com/pdf/EDUCATION-6-4-6.pdf

Mansor, N. A., Fatzel, F. H. M., Shamsudin, S. M., \& Anwar, I. S. K. (2019). Zakat Versus Taxation: An Overview of the Implementation in Malaysia. In Islamic Development Management (pp. 329-337). Springer, Singapore. https://doi.org/10.1007/978-981-13-7584-2_25

Marlina, L., Maifizar, A., \& Risma, O. R. (2020). optimization of zakat collection in west aceh: study from baitul mal in the early islamic government. PalArch's Journal of Archaeology of Egypt/Egyptology, 17(5), 121-135. Retrieved from https://www.archives.palarch.nl/index.php/jae/article/download/672/668

May, S. (2020). Islamic Charitable Giving in the UK: A 'Radical'Economic Alternative?. New Political Economy, 25(6), 913-925. https://doi.org/10.1080/13563467.2019.1664445

Md. Hashim, S. L. \& Leha A. F. (2017). Tax Payer's Obligation to Pay Zakat in Selangor. Journal of Humanities, Language, Culture and Business (HLCB), 1(6), 94-102. Retrieved from http://www.icohlcb.com/images/Articles/vol_1_No.6/Paper-100-.pdf

Mohsin, M. I. A., \& Ismail, M. (2013). Potential of zakat in eliminating riba and eradicating poverty in muslim countries. EJBM-Special Issue: Islamic Management and Business, 5(11), 114-126. Retrieved from https://www.semanticscholar.org/paper/Potential-of-Zakat-in-Eliminating-Ribaand-Poverty-Mohsin/f250eb17fb9fd238d7f9148ef696349059d5c681?p2df

Muhammad, S. A., \& Saad, R. A. J. (2016). Determinants of trust on zakat institutions and its dimensions on intention to pay zakat: A pilot study. Journal of Advanced Research in Business and Management Studies, 3(1), 40-46. Retrieved from http://www.akademiabaru.com/doc/ARBMSV3_N1_P40_46.pdf

Muhammad, S. A., \& Saad, R. A. J. (2016). Moderating Effect of Attitude toward Zakat Payment on the Relationship between Moral Reasoning and Intention to Pay 
Vol. 6 No. 1 (2021)

ISSN (print): 2502-3918 | ISSN (online): 2502-7824

Zakat. Procedia-Social and Behavioral Sciences, 219, 520-527. https://doi.org/10.1016/j.sbspro.2016.05.029

Muhammad, S. A., \& Saad, R. A. J. (2016). The impact of public governance quality, accountability and Effectiveness on intention to pay zakat: moderating effect of Trust on zakat institution. International Journal of Management Research and Reviews, 6(1), 1-8. https://www.researchgate.net/profile/Ram_Al_Jaffri_Saad/publication/318117072 THE_IMPACT_OF_PUBLIC_GOVERNANCE_QUALITY_ACCOUNTABILI TY_AND_EFFECTIVENESS_ON_INTENTION_TO_PAY_ZAKAT

Othman, Y. H., Yusuff, M. S. S., Saufi, M. S. A. Z., \& Hafsha, S. (2017). The influence of knowledge, Islamic religiosity and self-efficacy on the intention to pay income zakat among public educators in Kedah, Malaysia. International Journal of Academic Research in Business and Social Sciences, 7(11), 1117-1127. Retrieved from

https://pdfs.semanticscholar.org/4653/5b3eb82afd195e6bf5d5f2247efb8bc58fa9.p $\underline{\mathrm{df}}$

Rahman, S. M., Zakaria, M., Shaari, R., Nawi, N. A., \& Zain, N. A. M. (2019). Perceived corporate credibility, service quality, knowledge and self-efficacy with business zakat compliance. Journal of Islamic, Social, Economics and Development, 4(21), 125-133. Retrieved from http://www.jised.com/PDF/JISED2019-21-06-11.pdf

Rahman, S. M., Zakaria, M., Shaari, R., Nawi, N. A., \& Zain, N. A. M. (2019). Perceived corporate credibility, service quality, knowledge and self-efficacy with business zakat compliance. Journal of Islamic, Social, Economics and Development, 4(21), 125-133. Retrieved from http://www.jised.com/PDF/JISED2019-21-06-11.pdf

Retsikas, K. (2020). A Synthesis of Time: Zakat, Islamic Micro-finance and the Question of the Future in 21st-Century Indonesia. Springer Nature.

Saad, R. A. J., \& Farouk, A. U. (2019). A comprehensive review of barriers to a functional Zakat system in Nigeria. International Journal of Ethics and Systems. 35(1), 24-42. https://doi.org/10.1108/IJOES-06-2018-0090

Saad, A. Y. Q., \& Al Foori, A. M. (2020). Zakat and tax: A comparative study in Malaysia. International Journal of Innovation, Creativity and Change, 10(12), 140-151.

Retrieved

from https://www.ijicc.net/images/vol10iss12/101213_Saad_2020_E_R.pdf

Sanep, A., \& Hairunnizam, W. (2004). Persepsi dan kesedaran terhadap perluasan sumber zakat harta yang diikhtilaf. In Seminar Halatuju Zakat Korporat di Alaf Baru (pp. 35-62). Retrieved http://www.ukm.my/hairun/kertas\%20kerja/kesedaran\%20membayar\%20zakat\%2 Opendapatan.pdf

Sumai, S., Mutmainnah, A. N., \& Arsyad, M. (2019, October). Role of zakat in poverty reduction and food security. In IOP Conference Series: Earth and Environmental Science (Vol. 343, No. 1, p. 012254). IOP Publishing. Retrieved from https://iopscience.iop.org/article/10.1088/1755-1315/343/1/012254/meta

Takril, N. F., \& Othman, N. F. (2020). Effectiveness Of Zakat Collection And Distribution Of Zakat Counter At Higher Learning Institutions. International Journal of Islamic Economics and Finance Research, 3(2), 91-106. Retrieved from http://ijiefer.kuis.edu.my/ircief/article/view/35 
Taylor, S., \& Todd, P. (1995). Assessing IT usage: The role of prior experience. MIS quarterly, 19(4), 561-570. https://doi.org/10.2307/249633

Tsalas, N. A., Mahri, A. J. W., \& Rosida, R. (2019). Zakat Compliance Behaviour: Good Corporate Governance with Muzakki's Trust Approach (Survey on Muzakki of the National Board of Zakat (BAZNAS) in Garut). KnE Social Sciences, 796-808. Retrieved from https://www.knepublishing.com/index.php/KnE-Social/article/view/4248/8725

Zainal, H., Bakar, A. A., \& Saad, R. A. J. (2016). Reputation, satisfaction of zakat distribution, and service quality as determinant of stakeholder trust in zakat institutions. International Journal of Economics and Financial Issues, 6(7S), 7276.

Retrieved

from

https://www.researchgate.net/profile/Hafizah_Zainal2/publication/311387807_Re putation_Satisfaction_of_Zakat_Distribution_and_Service_Quality_

Zaenal, M. H., Choirin, M., Tsabita, K., Astuti, A. D., \& Sadariyah, A. S. (2017). Principles of amil zakat and best practice recommendations for zakat institutions. Working Papers-PUSKAS BAZNAS, 1. Retrieved from http://www.iconzbaznas.com/publications/index.php/pwps/article/view/19 